\title{
The death domain kinase RIP has an essential role in DNA damage-induced NF-KB activation
}

\author{
Gang Min Hur, ${ }^{1}$ Joseph Lewis, ${ }^{1}$ Qingfeng Yang, ${ }^{1}$ Yong Lin, ${ }^{1}$ Hiroyasu Nakano, ${ }^{2}$ Sergei Nedospasov, ${ }^{3}$ \\ and Zheng-gang Liu ${ }^{1,4}$ \\ ${ }^{1}$ Cell and Cancer Biology Branch, Center for Cancer Research, National Cancer Institute, National Institute of Health, \\ Bethesda, Maryland 20892, USA; ${ }^{2}$ Department of Immunology, Juntento University School of Medicine, Precursory Research \\ for Embryonic Science and Technology (PREST), Japan Science and Technology Corporation, Tokyo, Japan; ${ }^{3}$ Basic Research \\ Program, SAIC Frederick, National Cancer Institute, Frederick, Maryland 21702, USA
}

\begin{abstract}
The transcription factor NF-кB is activated when cells are exposed to genotoxic stress. It has been suggested that DNA damage will trigger a cytoplasmic signaling that leads to the activation of IKK and NF-кB, but the signaling components upstream of IKK have not yet been identified. Here we report that the receptor interacting protein, RIP, is the IKK upstream component, essential for the activation of NF-кB by DNA damage. Also, our findings suggest that this NF- $\mathrm{B}$ activation by DNA damage is not mediated by autocrine or TNF-R1 signaling pathway. In wild-type fibroblasts, DNA damage induced by agents such as adriamycin, campthothecin, and ionizing radiation induces NF-кB activation. We found, however, that DNA damage failed

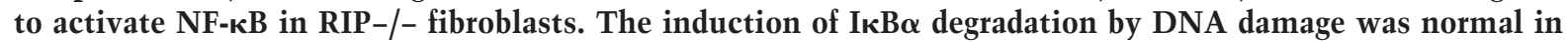
TNF-R1-/-, TRAF2-/-, TRAF5-/- and FADD-/- fibroblasts or when de novo protein synthesis was blocked. More importantly, the reconstitution of RIP expression in RIP-/- cells restores DNA damage-induced NF- $\mathrm{B}$ activation. We also found that RIP forms a complex with IKK in response to DNA damage. Therefore, our study provides a possible mechanism for the initiation of the cytoplasmic signaling to activate NF- $\mathrm{B}$ in response to DNA damage.
\end{abstract}

[Keywords: RIP; NF-кB; DNA damage; genotoxic stress; signaling]

Received November 27, 2002; revised version accepted February 6, 2003.

The cellular response to genotoxic stress, such as radiation and DNA damage, is partly mediated by transcription factors including NF-кB, AP-1, and p53 (Canman and Kastan 1996; Ko and Prives 1996; Liu et al. 1996a). These transcription factors elicit various biological responses through induction of target genes. Because NF$\kappa \mathrm{B}$ activation can have anti-apoptotic or pro-apoptotic effect, it is believed that NF-кB activation is a key cellular response that modulates the outcome of cells exposed to radiation and genotoxic drugs (Boland 2001; Laurent and Jaffrezou 2001). It is known that the NF- $\mathrm{B}$ regulates the expression of genes critical for a variety of biological processes, including immune responses, inflammatory reactions and apoptosis (Verma et al. 1995; Baeuerle and Baltimore 1996; Silverman and Maniatis 2001). In most types of cells, inactive NF- $\mathrm{B}$ is sequestered in the cytoplasm through its interaction with the inhibitory proteins known as IкBs (Siebenlist et al. 1994;

${ }^{4}$ Corresponding author.

E-MAIL zgliu@mail.nih.gov; FAX (301) 402-1997.

Article published online ahead of print. Article and publication date are at http://www.genesdev.org/cgi/doi/10.1101/gad.1062403.
Baeuerle and Baltimore 1996). In response to various stimuli, such as pro-inflammatory cytokines TNF and IL-1, IкBs are phosphorylated by their kinase, IKK, and are rapidly degraded by the proteasome after polyubiquitination (Brown et al. 1995; Karin and Ben-Neriah 2000). The degradation of IкBs leads to the release of NF-кB and allows its translocation into the nucleus and the subsequent activation of its targets genes (Baeuerle and Baltimore 1996). The IKK complex has three components: two catalytic subunits, IKK $\alpha$ and IKK $\beta$; and one regulatory subunit, IKK $\gamma$ (Karin and Ben-Neriah 2000; Li et al. 2000).

The molecular mechanism of NF- $\mathrm{B}$ activation by different stimuli has been intensively studied in the last several years and tremendous progress has been made (Karin and Ben-Neriah 2000; Silverman and Maniatis 2001). For TNF-induced IKK and NF- $\mathrm{kB}$ activation, two TNF effector molecules, the death domain kinase RIP (receptor interacting protein) and TRAF2 (TNFR-associated factor 2), have been found to be essential ( $\overline{\mathrm{Ch}}$ - $\mathrm{c}$ and Goeddel 2002). RIP was first identified as a Fas-interacting protein (Stanger et al. 1995). It was later demonstrated that RIP is a key component of the TNF-R1 sig- 
naling complex (Hsu et al. 1996). Genetic deletion experiments suggest that RIP is essential for TNF-induced NF-кB activation (Ting et al. 1996; Kelliher et al. 1998). The RIP protein contains three domains, including an $\mathrm{N}$-terminal kinase domain, an intermediate domain, and a C-terminal death domain (Stanger et al. 1995; Shu et al. 1996). RIP is recruited into the TNF-R1 complex by the TNF adapter protein, TRADD (TNF-ㅌ1-associated death domain protein). The intermediate domain of RIP interacts with TRAF2, and this interaction is required for RIP-mediated NF-кB activation (Hsu et al. 1996). In response to TNF treatment, IKK is recruited to TNF receptor complex through TRAF2 and its activation requires RIP (Devin et al. 2000). It has also been suggested that RIP interacts with the IKK complex through the regulatory subunit, IKK- $\gamma$, but apparently this interaction requires TRAF2 (Zhang et al. 2000; Devin et al. 2001). The molecular mechanism of genotoxic stress-induced NF$\kappa \mathrm{B}$ activation is, however, still largely unknown. It has been reported that ionizing radiation (IR) and short wavelength UV activate NF- $\mathrm{B}$ through two distinct pathways (Li and Karin 1998; Bender et al. 1998). It has been found that UV activates NF-кB through an IKK-independent pathway (Bender et al. 1998; Li and Karin 1998). For IR and DNA-damaging agents, it has been suggested that DNA damage will trigger a cytoplasmic signaling cascade, including the activation of IKK, to mediate NF- $\mathrm{B}$ activation (Li and Karin 1998; Huang et al. 2000), but the signaling components upstream of IKK have not been identified. It has been proposed previously that UV and DNA damage may activate NF- $\kappa$ B through the cell membrane receptors, such as TNF and IL-1 receptors (Devary et al. 1993; Hallahan et al. 1995; Bender et al. 1998). Therefore, it is important to determine whether RIP, the key effector of TNF signaling, is involved in the activation of NF-кB by UV or DNA damage. Using mouse RIP null (RIP-/-) fibroblasts, we demonstrated that RIP has an essential role in the activation of NF- $\kappa$ B by DNA damage and IR. We found that DNA damage-induced NF- $\kappa \mathrm{B}$ activation was not mediated by autocrine or TNFR1 signaling pathway. Our results also indicated that RIP functions upstream of IKK and activates IKK through forming a complex with IKK. Interestingly, other effector molecules, such as TRAF2 and TRAF5, of TNF signaling were not involved in DNA damage-induced NF- $\kappa$ B activation.

\section{Results}

RIP is required for DNA damage-induced $N F-\kappa B$ activation

The exposure of diverse types of mammalian cells to genotoxic stress, such UV and DNA damage, induces the activation of NF- $\mathrm{BB}$ (Li and Karin 1998; Huang et al. 2000; Bottero et al. 2001). The upstream components of the pathways that lead to the activation of NF-кB, however, are largely unknown. Because the death domain kinase RIP is a key effector of TNF-induced NF- $\mathrm{kB}$ activation (Hsu et al. 1996; Liu et al. 1996b; Ting et al. 1996;
Kelliher et al. 1998), we therefore tested whether RIP is involved in genotoxic stress-induced NF- $\mathrm{BB}$ activation using RIP null (RIP-/-) fibroblast cells. First, we tested whether RIP is involved in UV-induced NF- $\mathrm{BB}$ activation by treating wild-type or RIP-/- fibroblast cells with UVC $\left(20 \mathrm{~J} / \mathrm{m}^{2}\right)$. After treatment, cells were collected at different time points and used for analyzing IкB $\alpha$ degradation. As shown in the top panel of Figure $1 \mathrm{~A}, \mathrm{I} \kappa \mathrm{B} \alpha$ degradation following UV treatment was detected similarly in both wild-type and RIP-/- cells. The middle panel of Figure 1A shows that there is no expression of RIP protein in RIP-/- cells and the bottom panel of Figure 1A is the Western result with an anti-actin antibody as a proteinloading control of each sample. These results indicate that RIP is not involved in UV-induced NF-кB activation.

Because it has been reported that UV and DNA damage induce NF- $\mathrm{B}$ activation via distinct pathways (Bender et al. 1998; Li and Karin 1998), we then examined whether RIP is required for DNA damage-induced NF- $\mathrm{B}$ activation. Two DNA-damaging agents, adriamycin (Adr) and campthothecin (Cpt), were used to treat wild-type and RIP-/- cells. Following treatment, cells were collected at different time points and used to analyze I $\mathrm{B} \alpha \alpha$ degradation. As shown in the top panel of Figure $1 \mathrm{~B}$, when wild-type cells were treated with Adr, the degradation of $\mathrm{I}_{\kappa} \mathrm{B} \alpha$ protein started to be detected at about $5 \mathrm{~h}$ after treatment and the expression of IкB $\alpha$ protein was recovered by $12 \mathrm{~h}$. Treatment of Cpt also induced the degradation of $\mathrm{I} \kappa \mathrm{B} \alpha$ protein in wild-type cells (Fig. 1B, bottom panel). The treatment of Cpt, however, caused a quicker response as $\mathrm{I}_{\kappa} \mathrm{B} \alpha$ degradation was first detected at $1 \mathrm{~h}$ after treatment and the recovery of I $\mathrm{B} \alpha$ expression was detected at $5 \mathrm{~h}$ after treatment (Fig. 1B, bottom panel). Surprisingly, there was no detectable degradation of $\mathrm{I}_{\kappa} \mathrm{B} \alpha$ protein in RIP-/- cells after either $\mathrm{Adr}$ or Cpt treatment (Fig. 1B). Importantly, the IкB $\alpha$ degradation in response to IL- $1 \beta$ and bacterial lipopolysaccharide (LPS) treatment is normal in RIP-/- cells, as compared with wild-type cells, as shown in Figure 1C (top and bottom panels). These results suggest that RIP may be involved in DNA damage-induced NF-кB activation.

To further confirm that RIP is required for DNA damage-induced NF- $\mathrm{B}$ activation, we examined the induction of NF- $\kappa$ B activity by EMSA using a NF- $\mathrm{B}$-specific probe. As expected, no NF- $\mathrm{B}$ activation was observed in Adr- or CPT-treated RIP-/- cells, whereas an increase in NF-кB DNA-binding activity in response to Adr or Cpt treatment was evident in wild-type cells (Fig. 2A,B). The kinetics of NF- $\mathrm{B}$ activation in wild-type cells correlated well with the kinetics of IкB $\alpha$ degradation by these drugs as shown in Figure 1B. Because ionizing radiation (IR) also induces NF-кB activation (Singh and Lavin 1990; Li and Karin 1998), we examined whether RIP is required for IR-induced NF-кB activation. Like DNA-damaging drugs, exposure of wild-type cells to IR resulted in the induction of NF-кB DNA-binding activity (Fig. 2C). Increased NF-кB DNA-binding activity induced by IR was first detected $3 \mathrm{~h}$ post-radiation, and maximal induction 
A

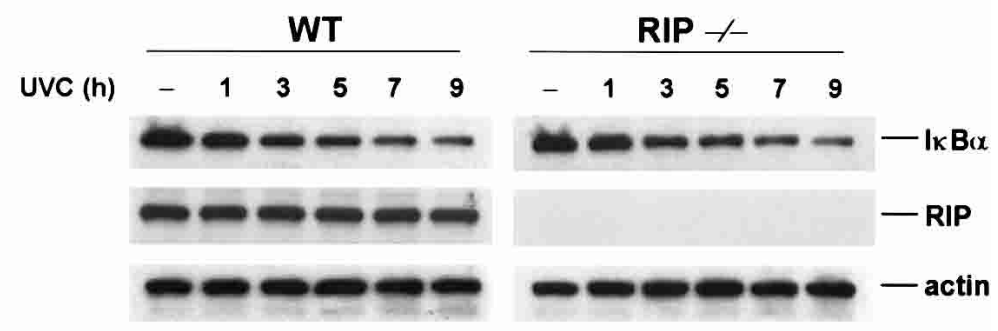

B
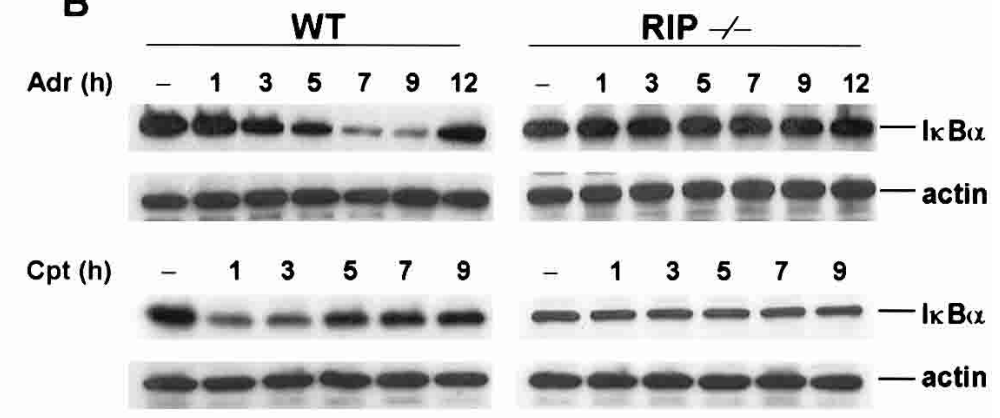

C
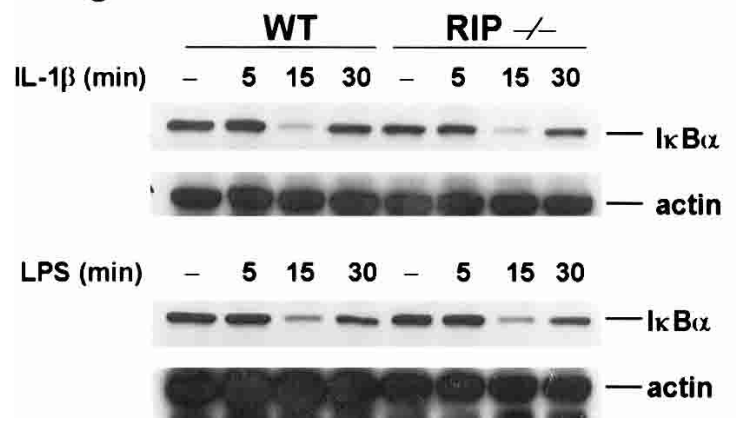

Figure 1. RIP is essential for the induction of $\mathrm{I \kappa}_{\kappa} \mathrm{B}$ degradation by DNA damage. (A) RIP is not required for UV-induced $\mathrm{I} \kappa \mathrm{B}_{\alpha}$ degradation. Mouse wild-type (WT) and RIP-/- fibroblasts were exposed to UV-C $\left(20 \mathrm{~J} / \mathrm{m}^{2}\right)$ and cell extracts were prepared as described in Materials and Methods. Cell extracts were applied to SDS-PAGE for Western blotting with antiІкB $\alpha$ anti-RIP and anti- $\beta$-actin antibodies. (B) Degradation of IкB $\alpha$ induced by adriamycin (Adr) and comptothecin (Cpt). Mouse wild-type and RIP-/- fibroblasts were incubated with $\mathrm{Adr}(10 \mu \mathrm{g} / \mathrm{mL})$ or Cpt $(100 \mu \mathrm{M})$ for various times as indicated. Cell extracts were applied to SDS-PAGE for Western blotting with anti-IкB $\alpha$ and anti- $\beta$-actin antibodies. $(C)$ Degradation of IкB $\alpha$ induced by lipopolysaccharide (LPS) and interleukin-1 $\beta$ (IL-1 $\beta$ ). Mouse wild-type and RIP-/- fibroblasts were incubated with LPS (10 ng/ $\mathrm{mL})$ or IL-1 $\beta(15 \mathrm{ng} / \mathrm{mL})$ for various times as indicated. Cell extracts were applied to SDS-PAGE for Western blotting with anti-IкB $\alpha$ and anti- $\beta$-actin antibodies.

was observed 5-7 h after radiation exposure. In contrast, in the RIP-/- cells, IR fails to induce the NF-кB DNAbinding activity. We also confirmed that NF- $\mathrm{B}$ DNAbinding activity in response to IL- $1 \beta$ treatment is normal in both types of cells (Fig. 2D). As a control of nuclear protein contents, the Sp-1 protein level in wild-type and RIP-/- cells was examined by Western blotting with an anti-Sp-1 antibody and no difference was observed (Fig. 2A-D, bottom panels). To rule out the possibility that some other defects in the signaling pathway of DNA damage-mediated NF- $\kappa \mathrm{B}$ activation are present in RIP-/cells, we tested whether DNA damage-induced NF-кB activation could be reconstituted by ectopic expression of RIP. To do so, we generated RIP stably transfected cell line [RIP-/-(RIP)]. The expression level of RIP in RIP reconstituted cells is lower than in wild-type cells as measured by Western blotting (Fig. 3A). As shown in Figure $3 \mathrm{~B}$, RIP reconstitution is able to restore IкB- $\alpha$ degradation in response to $\mathrm{Adr}$ treatment in $\mathrm{RIP}-/-(\mathrm{RIP})$ cells. Because of the lower expression level of RIP in RIP-/-(RIP) cells, the degradation of IкB $\alpha$ in those cells is not as dramatic as in wild-type cells in response to $\mathrm{Adr}$ treatment. The reconstitution of the NF- $\kappa$ B activation by ectopic expression of RIP in RIP-/- cells, however, is more evident by gel-shift assays as shown in Figure 3C. These results demonstrate that the defect in DNA damage-induced NF- $\mathrm{KB}$ activation in RIP-/- cells is attributable to the absence of RIP. Taken together, our data suggest that RIP is required for DNA damage-induced NF-кB activation.

\section{$N F-\kappa B$ activation by DNA damage is independent of TNF signaling}

Previous studies have suggested that UV and DNA damage could induce the synthesis and release of cytokines (Hallahan et al. 1995; Bender et al. 1998; Kulms et al. 2000). To rule out the possibility that the requirement of RIP in DNA damage-induced NF- $\kappa \mathrm{B}$ activation is caused by the autocrine action of cytokines, we tested whether $\mathrm{I} \kappa \mathrm{B} \alpha$ is degraded in the presence of cycloheximide (CHX) in response to DNA damage. As shown in Figure 4A, $\mathrm{CHX}$ has no effect on IкB $\alpha$ degradation induced by $\mathrm{Adr}$, indicating that DNA damage-induced NF- $\kappa$ B activation does not require de novo protein synthesis and it is unlikely that the newly synthesized cytokines, such as 
Hur et al.

Figure 2. Impaired activation of NF- $\kappa \mathrm{B}$ by DNA damage and ionizing radiation (IR) in RIP-/- fibroblast cells. $(A-C)$. Kinetics of NF$\kappa \mathrm{B}$ activation by Adr, Cpt, and IR. Mouse wild-type and RIP-/- fibroblasts were treated with $10 \mu \mathrm{g} / \mathrm{mL}$ of $\operatorname{Adr}(A), 100 \mu \mathrm{M}$ of $\mathrm{Cpt}(B)$, or 80 Gy of IR $(C)$ for various times as indicated. Nuclear extracts were prepared and 5 $\mu \mathrm{g}$ of the nuclear extract from each sample was used to analyze NF- $\mathrm{BB}$ activity by EMSA with a NF- $\kappa$ B probe. As a control, $50 \mu \mathrm{g}$ of the nuclear extract from each sample was applied to SDS-PAGE for Western blotting with antiSp-1 antibody. (D) IL-1 $\beta$-induced NF-кB activation. Mouse wild-type and RIP-/- fibroblasts were stimulated with mouse IL-1 $\beta$ (15 $\mathrm{ng} / \mathrm{mL}$ ) for various times as indicated. Nuclear extracts were prepared and $5 \mu \mathrm{g}$ of each sample was used to analyze NF-кB activity by EMSA with a NF-кB probe.

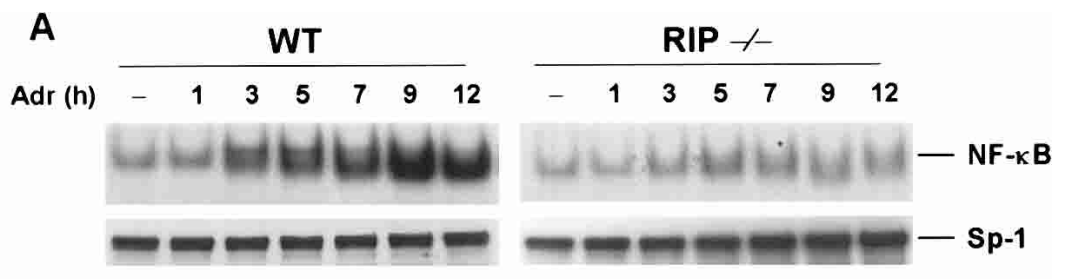

B

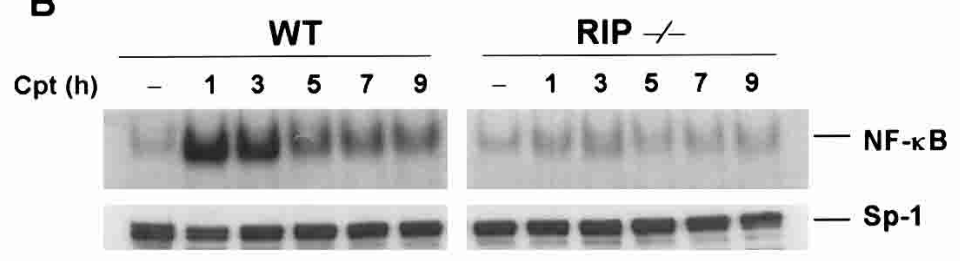

C
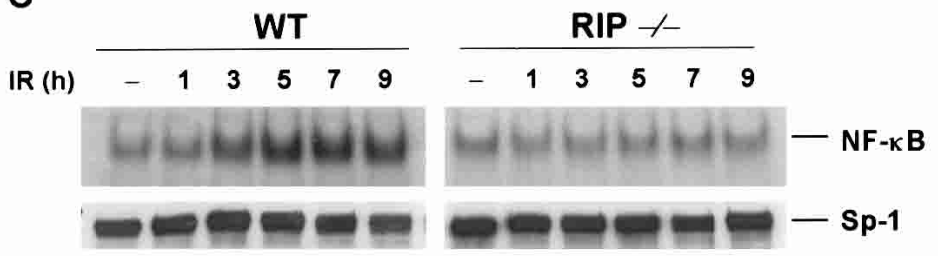

D

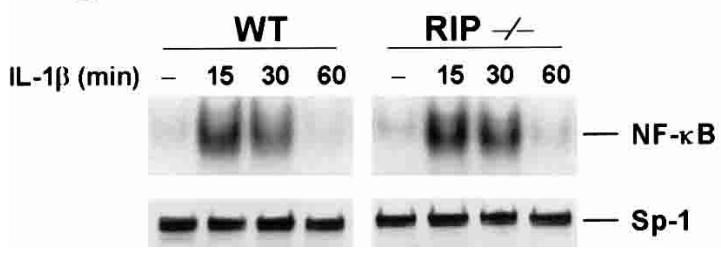

TNF, are responsible for this process. It has been shown previously that RIP is essential for TNF-induced NF-кB activation (Hsu et al. 1996; Ting et al. 1996; Devin et al. 2000; Zhang et al. 2000). To further rule out the involvement of TNF signaling in DNA damage-induced NF-кB activation, we examined the IкB $\alpha$ degradation in TNFR1-/- MEF cells. We found that Adr treatment resulted in a similar level and kinetics of $\mathrm{I}_{\kappa} \mathrm{B} \alpha$ degradation in the TNF-R1-/- cells, as compared to wild-type cells (Fig. 4B, top panel). The expression of TNF-R1 in these two types of cells is shown in the middle panel of Figure 4B. To be sure that TNF signaling is defective in TNF-R1-/- cells, TNF-induced I $\mathrm{B} \alpha$ degradation was examined. As shown in Figure 4C, whereas TNF induced $\mathrm{I}_{\kappa} \mathrm{B} \alpha$ degradation in wild-type cells, no IкB $\alpha$ degradation was detected in TNF-R1-/- cells. Therefore, DNA damage-induced NF$\kappa \mathrm{B}$ activation is independent of TNF signaling.

To address whether other effector proteins of TNF signaling, such as TRAF2, TRAF5, and FADD, are involved in DNA damage-induced NF- $\mathrm{B}$ activation, we examined I $\mathrm{B} \alpha$ degradation in response to $\mathrm{Adr}$ treatment in TRAF2-/-, TRAF5-/- and FADD-/- mouse fibroblast cells. The protein expression levels of FADD, TRAF2, and TRAF5 in those cells are shown in Figure 5A. When those cells were treated with Adr, as shown in Figure 5B, Iк $\mathrm{B} \alpha$ was degraded with the similar degree and kinetics as in wild-type cells. Therefore, unlike RIP, TRAF2, TRAF5, and FADD are not required for DNA damageinduced NF- $\kappa \mathrm{B}$ activation.

DNA damage induces the formation of IKK and RIP complex

Previous studies have suggested that IKK is involved in the activation of $\mathrm{NF}-\kappa \mathrm{B}$ in response to IR and other DNA-damaging agents (Li and Karin 1998; Bottero et al. 2001). To confirm this observation, we tested the activation of NF- $\kappa B$ in response to DNA damage in the IKK- $\beta$ null (IKK $\beta-/-$ ) fibroblasts. Consistent with previous findings (Li and Karin 1998; Bottero et al. 2001), NF$\kappa \mathrm{B}$ activation induced by Adr (Fig. 6A) or Cpt (data not shown) was abolished in IKK $\beta$-/- cells as no IкB $\alpha$ degradation was detected. Because the recruitment of IKK to RIP through TRAF2 has been implied to be the key event for IKK activation in response to TNF treatment (Devin et al. 2001), we then examined whether IKK interacts with RIP following DNA damage. To test this possibility, wild-type cells were treated with Adr for different times (2-6 h) and then cell extracts were collected for immunoprecipitation experiments with an anti-IKK- $\gamma$ antibody. The immunoprecipitants were analyzed by Western blotting with anti-RIP, anti-TRADD, and IKK $\beta$ 


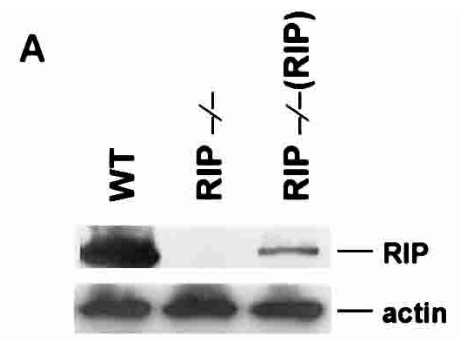

B

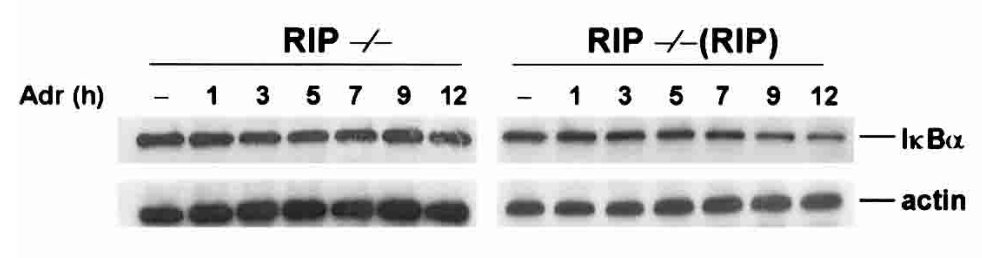

C

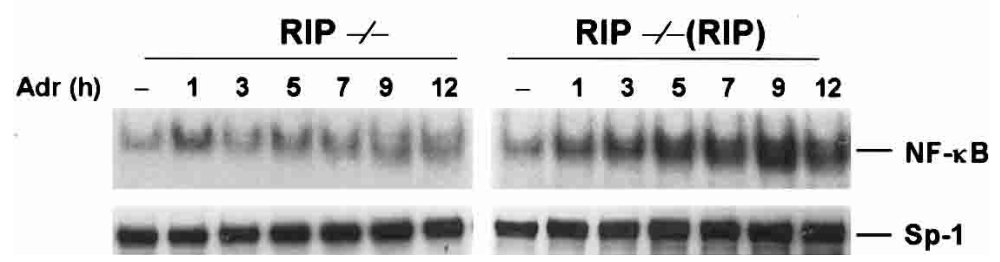

Figure 3. Expression of RIP reconstituted DNA damage-induced I $\mathrm{K} \mathrm{B} \alpha$ degradation and NF- $\kappa \mathrm{B}$ activity in RIP-/-(RIP) fibroblast cells. (A) The protein expression levels of RIP in wild-type, RIP-/-, and RIP reconstituted stable cell lines of RIP-/- [RIP-/-(RIP)] fibroblasts. The same amount of cell extract from each cell line was applied to SDS-PAGE for Western blotting with anti-RIP and anti- $\beta$-actin antibodies. $(B)$ Reconstitution of Adr-induced IкB $\alpha$ degradation in RIP-/ -(RIP) cells. Mouse RIP-/- and RIP-/-(RIP) cells were incubated with $\operatorname{Adr}(10 \mu \mathrm{g} / \mathrm{mL})$ for various times as indicated. Cell extracts were applied to SDS-PAGE for Western blotting with anti-IкB $\alpha$ and anti- $\beta$-actin antibodies. $(C)$ Reconstitution of Adr-induced NF-кB binding activities in RIP-/-(RIP) cells. Mouse RIP-/- and RIP-/-(RIP) cells were incubated with Adr $(10 \mu \mathrm{g} / \mathrm{mL})$ for various times as indicated in the figure. NF- $\mathrm{kB}$ activity was measured by EMSA as described in Figure 2. antibodies, respectively. As shown in the top panel of Figure 6B, whereas the interaction between RIP and IKK was barely detected in nontreated cells and in the cells treated with Adr for $2 \mathrm{~h}$, this interaction is dramatically increased after 4-6 h of Adr treatment. The kinetics of this interaction correlated well with the ones of IкB $\alpha$ degradation and NF- $\kappa$ B activation (Figs. 1B, 2A). When the blot was probed with an antibody against TRADD, a key adapter protein in TNF receptor complex, no TRADD was found in the immunoprecipitants (Fig. 6B, middle panel). Because TRADD exists in the TNFR1IKK complex in response to TNF treatment (Devin et al. 2000), the formation of RIP-IKK complex in response to DNA damage is different from the one induced by TNF. As a control, IKK $\beta$ level in the immunoprecipitants was measured and the results are shown in Figure 6B, bottom panel, indicating that the same amount of IKK was precipitated in each sample. In our previous study, we found that the RIP-IKK interaction induced by TNF is mediated by TRAF2 (Devin et al. 2000). To check whether the RIP-IKK interaction in response to DNA damage also requires TRAF2, we performed similar immunoprecipitation experiments, as described in Figure 6B, with TRAF2-/- cells. Surprisingly, as shown in Figure 6C, the formation of RIP-IKK complex in TRAF2-/- cells was as efficient as in wild-type cells. This result further indicates that the RIP-mediated NF- $\kappa$ B activation in response to DNA damage is distinct from TNF-induced NF-кB activation. Moreover, because a previous study suggested that the serine/threonine protein kinase ATM is required for DNA double-strand breaks-induced NF-кB activation (Li et al. 2001), we then examined whether ATM has a role in RIP-IKK interaction in response to DNA damage by performing immunoprecipitation experiments in ATM-/- fibroblasts. As shown in Figure $6 \mathrm{D}$, the interaction of RIP and IKK could not be detected in the absence of ATM. Therefore, ATM is required for DNA damage-induced formation of IKK-RIP complex.

In previous studies, it has been shown that the kinase activity of RIP is not required for mediating TNF-induced NF- $\kappa$ B activation (Hsu et al. 1996; Liu et al. 1996b; Devin et al. 2000). To check whether the kinase activity of RIP is required for DNA damage-induced NF- $\mathrm{B}$ activation, we tested if the kinase-inactive RIP mutant can restore DNA damage-induced NF- $\mathrm{B}$ activation in RIP-/- cells. This was done by NF-кB luciferase reporter assay. As shown in Figure 7A, Adr and Cpt induced twoto threefold NF- $\kappa$ B activation in wild-type cells, measured by luciferase reporter assay, but both Adr and Cpt failed to do so in RIP-/- cells. TNF and IL-1 treatments served as controls. When wild-type RIP was expressed in RIP-/- cells, the impaired NF- $\kappa$ B activation by Adr was restored (Fig. 7B). The kinase-inactive RIP mutant $\mathrm{RIP}(\mathrm{K} 45 \mathrm{~A})$ has shown the same effect as the wild-type RIP (Fig. 7B). Therefore, the kinase activity of RIP is unlikely to be involved in DNA damage-induced NF-кB activation. To further confirm this observation, we also generated stably transfected RIP-/- cells with the $\mathrm{RIP}(\mathrm{K} 45 \mathrm{~A})$ plasmid (Fig. 7C). As shown in Figure 7D, the $\mathrm{RIP}(\mathrm{K} 45 \mathrm{~A})$ protein could restore the Adr-induced activa- 
Hur et al.

Figure 4. IкB $\alpha$ degradation induced by $\mathrm{Adr}$ is independent of autocrine and TNF receptor signaling. $(A)$ Adrinduced IкB- $\alpha$ degradation does not require de novo protein synthesis. Mouse wild-type fibroblasts were treated with or without $1 \mu \mathrm{M}$ cyclohexamide (CHX) for $30 \mathrm{~min}$ and then with $\mathrm{Adr}(10 \mu \mathrm{g} / \mathrm{mL})$ for $7 \mathrm{~h}$. Cell extracts were prepared for Western blottings with antiІкB $\alpha$ and anti- $\beta$-actin antibodies. (B) Adr-induced ІкB $\alpha$ degradation is independent of TNF receptor 1 signaling. Mouse wild-type and TNF-R1-/- cells were incubated with $\mathrm{Adr}(10 \mu \mathrm{g} / \mathrm{mL})$ for various times as indicated. Cell extracts were applied to SDS-PAGE for Western blotting with anti-IкB $\alpha$, anti-TNF-R1, and anti- $\beta$-actin antibodies. (C) Absence of IкB $\alpha$ degradation in response to TNF- $\alpha$ in TNF-R1-/- cells. Mouse wild-type and TNF$\mathrm{R} 1-/$ - cells were incubated with TNF- $\alpha(15 \mathrm{ng} / \mathrm{mL})$ for various times as indicated and cell extracts were analyzed with anti-ІкВ $\alpha$ and anti- $\beta$-actin antibodies.
A

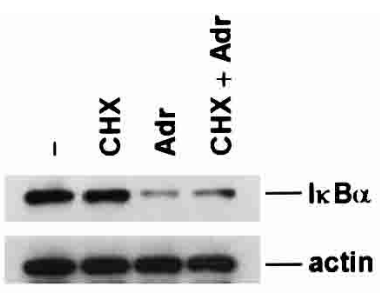

B

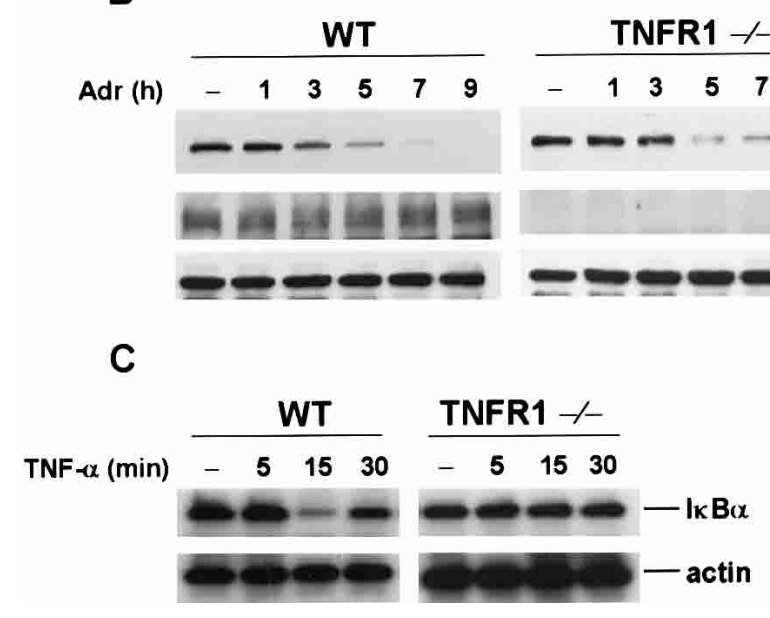

tion of NF-кB in RIP-/- cells as efficiently as wild-type RIP, measured by EMSA.

\section{Discussion}

The activity of NF-кB can be induced by genotoxic stress, such as UV and DNA damage, and is an important cellular response that modulates the fate of cells exposed to those stresses (Bender et al. 1998; Li and Karin 1998; Boland 2001; Bottero et al. 2001). Although much effort has been made to study the molecular mechanism of NF- $\kappa \mathrm{B}$ activation in response to genotoxic stress, the signaling cascade that leads to NF- $\mathrm{B}$ activation largely remains to be identified. In this study, we demonstrated that the death domain kinase RIP has an essential role in DNA damage-induced NF- $\kappa \mathrm{B}$ activation. More importantly, the involvement of RIP in this process is independent of TNF receptor signaling. Therefore, we proposed that, on receiving the nuclear signal in response to DNA damage, RIP initiated the cytoplasmic signaling that activates NF-кB.

Previous studies have suggested that NF-кB activation by genotoxic stress was mediated through cell surface receptors, such as TNF receptor 1 and IL-1 receptor (Devary et al. 1993; Hallahan et al. 1995; Bender et al. 1998). Because RIP is a key component of TNF-R1 signaling complex and has a pivotal role in TNF-induced NF- $\mathrm{B}$ activation (Kelliher et al. 1998; Devin et al. 2000), we examined the role of RIP in NF-кB activation by geno- toxic stress to address whether TNF signaling is involved. Consistent with earlier reports that UV and DNA damage activate NF- $\mathrm{B}$ through two distinct pathways (Bender et al. 1998; Li and Karin 1998), we found that RIP was only required for DNA damage-induced NF- $\kappa \mathrm{B}$ activation, and not for UV-induced NF- $\kappa \mathrm{B}$ activation. As RIP is only required for TNF-induced, but not IL-1-induced, NF-кB activation, this finding raised the possibility that DNA damage-induced NF- $\kappa$ B activation is mediated by TNF signaling and, at the same time, ruled out the involvement of IL-1 receptor. When de novo protein synthesis was blocked with the protein synthesis inhibitor CHX or TNF signaling was abolished (TNF-R1-/- fibroblasts; Fig. 4), however, DNA damageinduced NF- $\mathrm{\kappa B}$ activation was not affected. These results suggested that DNA damage-induced NF- $\mathrm{B}$ activation was not achieved through an autocrine pathway or TNF signaling, although RIP was required. This conclusion was supported further by the fact that other effectors of TNF-induced NF- $\kappa \mathrm{B}$ activation, TRAF2 and TRAF5, were not involved in DNA damage-induced NF- $\kappa$ B activation (Fig. 5). Therefore, DNA damage-induced NF-кB activation requires RIP, but not TNF signaling.

An early study reported that IKK was involved in NF$\kappa \mathrm{B}$ activation in response to IR (Li and Karin 1998). Here, we confirm the requirement of IKK in DNA damageinduced NF- $\mathrm{\kappa B}$ activation with IKK- $\beta-/$ - fibroblasts (Fig. 6). Previously, others and we have shown that IKK interacted with RIP when it was recruited to TNF-R1 com- 
A

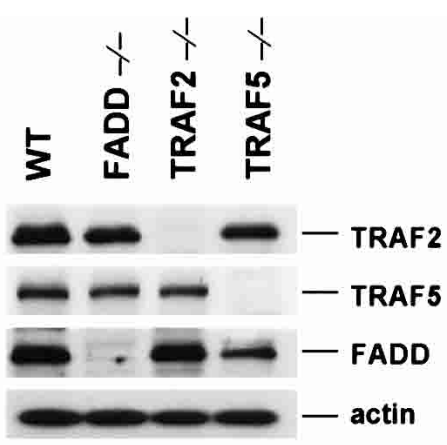

B

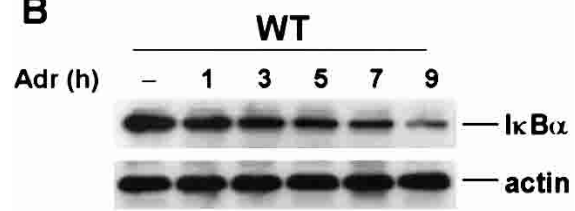

TRAF2-1-

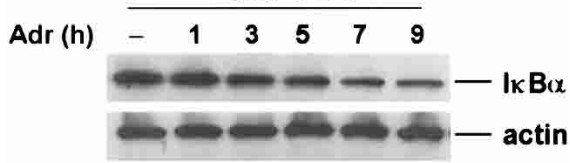

TRAF5-/-

Adr (h)

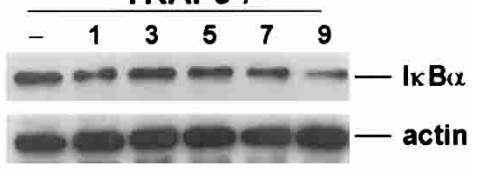

FADD-/-

Adr (h)

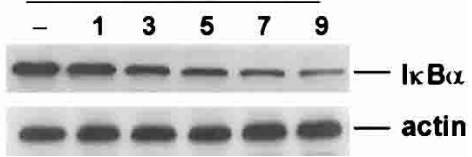

Figure 5. Adr-induced IкB $\alpha$ degradation in TRAF2-/-, TRAF5-/-, and FADD-/- fibroblasts. (A) Protein expression levels of TRAF2, TRAF5, FADD, and $\beta$-actin in wild-type, TRAF2-/-, TRAF5-/-, and FADD-/- fibroblasts. The equal amount of cell extract from each cell line was applied to SDSPAGE for Western blotting with anti-TRAF2, anti-TRAF5, anti-

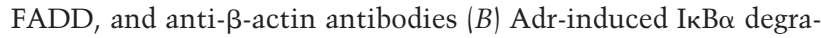
dation in wild-type, TRAF2-/-, TRAF5-/-, and FADD-/- fibroblasts. Mouse wild-type, TRAF2-/-, TRAF5-/-, and FADD-/fibroblasts were treated with $\operatorname{Adr}(10 \mu \mathrm{g} / \mathrm{mL})$ for various times as indicated. Cell extracts were applied to SDS-PAGE for Western blotting with anti-ІкB $\alpha$ and anti- $\beta$-actin antibodies.

plex (Devin et al. 2000; Zhang et al. 2000). In response to TNF treatment, the recruitment of IKK to TNF-R1 was mediated by TRAF2 (Devin et al. 2001). In this study, we also detected the interaction of RIP and IKK in response to DNA damage (Fig. 6). Different from the response to TNF treatment, however, the interaction between RIP and IKK induced by DNA damage does not require the presence of TRAF2 (Fig. 6). Currently, it is not clear whether RIP and IKK interact directly and the underlying mechanism of this interaction needs more investiga- tion. Nevertheless, this difference of the interaction of RIP and IKK further distinguished DNA damage-induced NF- $\kappa \mathrm{B}$ activation from the activation of NF- $\kappa \mathrm{B}$ by TNF. In addition, because the kinetics of the recruitment of IKK to RIP in response to DNA damage correlated well with the one of NF- $\kappa$ B activation (Figs. 1, 2, 6), it is likely that this recruitment is an early event in the activation of IKK by DNA damage. For TNF-induced IKK and NF$\kappa \mathrm{B}$ activation, RIP is essential but its kinase activity is dispensable (Hsu et al. 1996; Devin et al. 2000). We examined whether the kinase activity of RIP is required for DNA damage-induced NF- $\kappa$ B activation and found that the kinase activity of RIP was not required (Fig. 7). Therefore, RIP may activate IKK through the same mechanism in response to both TNF treatment and DNA damage.

In this report, we demonstrated that RIP is essential in DNA damage-induced NF- $\mathrm{KB}$ activation. However, it is still unclear how RIP senses the signal triggered by DNA damage. Because RIP is not a nucleocytoplasmic shuttling protein (data not shown) and DNA damage response starts in the nucleus, one possibility is that, in response to DNA damage, some nuclear proteins are exported from the nucleus and interact with RIP. This interaction will then lead to the aggregation of RIP and the formation of signaling complex with IKK. Therefore, identification of RIP interacting proteins in response to DNA damage will be critical for understanding the mechanism of signal transduction from nucleus to RIP. Identification of RIP interacting proteins will also help to define whether RIP is the initiating point for the cytoplasmic signaling cascade that leads to NF- $\kappa$ B activation in response to DNA damage.

\section{Materials and methods}

\section{Reagents}

Anti-RIP antibody was purchased from Transduction Laboratories. Anti-IкB- $\alpha$, anti-TRAF2, anti-TRAF5, anti-Sp1, antiXpress, and anti-TRADD were purchased from Santa Cruz Biotechnology. Anti-FADD is a gift from Dr. J. Zhang. Anti-JNK-1 and anti-IKK- $\beta$ were purchased from Pharmingen. Anti- $\beta$-actin, bacterial LPS were purchased from Sigma. Adriamycin and campthothecin were purchased from Calbiochem. Anti-TNFR1, Recombinant mouse TNF- $\alpha$ and IL- $1 \beta$ was purchased from R\&D Systems. Protein A sepharose was purchased from Amersham Pharmacia Biotech. The mammalian expression plasmids RIP, its mutants, and CrmA have been described previously (Hsu et al. 1996; Liu et al. 1996b).

\section{Cell culture and transfection}

Wild-type, RIP-/-, TRAF2-/-, TRAF5-/-, FADD-/-, IKK $\beta-/-$, and ATM-/- mouse fibroblast cells were cultured in Dulbecco's modified Eagle medium supplemented with $10 \%$ fetal bovine serum, $2 \mathrm{mM}$ glutamine, $100 \mathrm{U} / \mathrm{mL}$ penicillin, and $100 \mu \mathrm{g} / \mathrm{mL}$ streptomycin. TNFR1-/- MEF cells were generated from TNFR1 knockout mice. RIP reconstituted stable cell lines (RIP-/-/RIP) or [RIP-/-/RIP(K45A)] were also cultured in this medium including $300 \mu \mathrm{g} / \mathrm{mL}$ hygromycin. Transfection experi- 
A

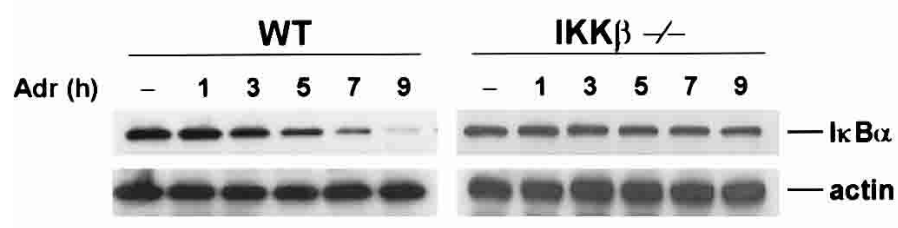

C

Adr (h)

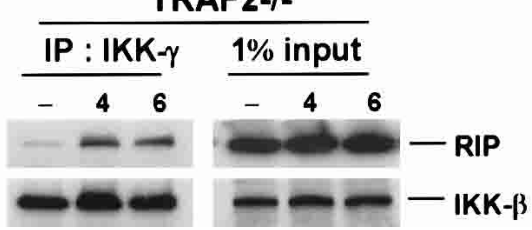

B

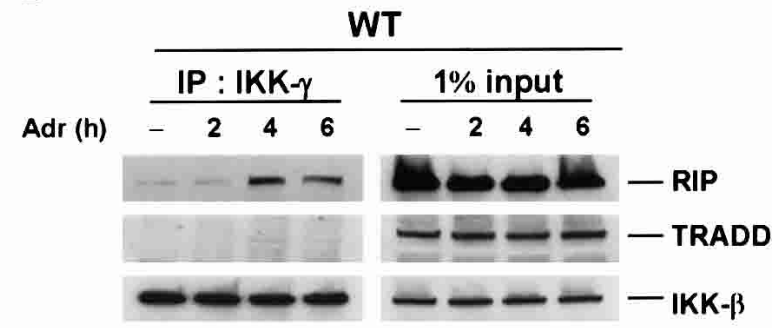

D

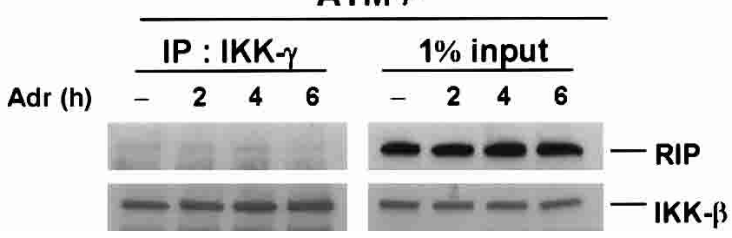

Figure 6. Adr induces the formation of IKK and RIP complex. (A) Adr-induced IкB $\alpha$ degradation requires IKK. Mouse wild-type and IKK- $\beta-/$ - cells were incubated with Adr $(10 \mu \mathrm{g} / \mathrm{mL})$ for various times as indicated. Cell extracts were applied to SDS-PAGE for Western blotting with anti-IкB $\alpha$ and anti- $\beta$-actin antibodies. $(B-D)$. Adr induces the formation of IKK and RIP complex. Cell extracts were prepared from mouse wild-type $(B)$, TRAF2-/- $(C)$, and ATM-/- cells $(D)$ after being treated with Adr $(10 \mu g / \mathrm{mL})$ for various times as indicated. Cell extract from each sample was immune-precipitated with an anti-IKK- $\gamma$ antibody overnight. Immune-precipitants were analyzed by Western blotting with anti-RIP, anti-TRADD, and anti-IKK- $\beta$ antibodies. One percent of cell extract from each sample was used as a control of protein input.

ments in RIP-/- cells were performed with Lipofectamine PLUS reagent by following the instruction provided by manufacturer (GIBCO-BRL).

\section{Western blot analysis and coimmunoprecipitation}

After treatment with different reagents as described in the figure legends, cells were collected and lysed in M2 buffer $(20 \mathrm{mM}$ Tris at $\mathrm{pH} 7,0.5 \% \mathrm{NP}-40,250 \mathrm{mM} \mathrm{NaCl}, 3 \mathrm{mM}$ EDTA, $3 \mathrm{mM}$ EGTA, 2 mM DTT, 0.5 mM PMSF, $20 \mathrm{mM} \beta$-glycerol phosphate, $1 \mathrm{mM}$ sodium vanadate, $1 \mu \mathrm{g} / \mathrm{mL}$ leupeptin). Fifty micrograms of the cell lysates was fractionated by SDS-polyacrylamide gel and Western blotted. The proteins were visualized by enhanced chemiluminescence (ECL), according to the manufacturer's instruction (Amersham).

For immunoprecipitation assays of endogenous proteins, $5 \times 10^{7}$ of mouse wild-type fibroblasts were treated with Adr (10 $\mu \mathrm{g} / \mathrm{mL}$ ) as indicated in the legend of Figure 6, collected in lysis buffer (50 mM HEPES at pH 7.6, $250 \mathrm{mM} \mathrm{NaCl}, 0.1 \% \mathrm{NP}-40,5$ mM EDTA, $0.5 \mathrm{mM}$ PMSF, $1 \mu \mathrm{g} / \mathrm{mL}$ leupeptin, $1 \mu \mathrm{g} / \mathrm{mL}$ aprotinin, $1 \mu \mathrm{g} / \mathrm{mL}$ pepstatin). The lysates were mixed and precipitated with the relevant antibody and protein A-Sepharose beads by incubation at $4^{\circ} \mathrm{C}$ for $4 \mathrm{~h}$ to overnight. The beads were washed four times with $1 \mathrm{~mL}$ of lysis buffer, and the bound proteins were resolved in 4\%-20\% SDS-polyacrylamide gels and detected by Western blot analysis.

\section{Electrophoretic mobility shift assay (EMSA)}

Nuclear extracts for EMSA were prepared from wild-type, RIP-/-, RIP-/-/RIP, and RIP-/-/RIP(K45A) cells as described previously (Devary et al. 1993) with minor modification. For binding reaction, $5 \mu \mathrm{g}$ of nuclear extract was incubated at room temperature for $20 \mathrm{~min}$ with reaction buffer containing $20 \mathrm{mM}$ HEPES at pH 7.9, $50 \mathrm{mM} \mathrm{KCl}, 0.1 \mathrm{mM}$ EDTA, $1 \mathrm{mM} \mathrm{DTT}, 5 \%$ glycerol, $200 \mu \mathrm{g} / \mathrm{mL}$ BSA, and $2 \mu \mathrm{g}$ of poly(dI-dC).poly(dI-dC). Then the ${ }^{32} \mathrm{P}$-labeled double-stranded oligonucleotide $(1 \mathrm{ng}$, $\geq 1 \times 105 \mathrm{cpm})$ containing the NF- $\kappa B$ binding consensus sequence (5'-GGCAACTGGGGACTCTCCCTTT-3') was added to the reaction mixture for an additional $10 \mathrm{~min}$ at room temperature. The reaction products were fractionated on a nondenaturating $6 \%$ polyacrylamide gel, which was then dried and subjected to autoradiography.

\section{Luciferase assay}

Wild-type cells and RIP-/- cells were cotransfected with p2XNF- $k$ B-Luc, pRSV- $\beta$-galactosidase and different RIP constructs as indicated in the figure legends. Twenty-four hours after transfection, cells were treated with Adr $(10 \mu \mathrm{g} / \mathrm{mL})$, Cpt $(100 \mu \mathrm{M}), \mathrm{TNF}-\alpha(30 \mathrm{ng} / \mathrm{mL})$, or IL- $1 \beta(4 \mathrm{ng} / \mathrm{mL})$ for an additional $10 \mathrm{~h}$, and luciferase activities in these cells were measured using a luciferase assay kit (Promega). Luciferase activity was normalized relative to the $\beta$-galactosidase activity of each sample.

\section{Acknowledgments}

We thank Dr. M. Kelliher for RIP-/- fibroblasts; Drs. W-C. Yeh and T.W. Mak for TRAF2-/- fibroblasts; Dr. M. Karin for IKK $\beta$-/- fibroblasts; Dr. J.Y.J. Wang for ATM-/- fibroblasts; and Dr. J. Zhang for FADD-/- fibroblasts and anti-FADD antibody. S.A.N. is supported by NCI contract NC1-CO-12400 and H.N. is supported by a grant from Human Frontier Science Program. We thank Dr. Swati Choksi for her assistance in manuscript preparation.

The publication costs of this article were defrayed in part by payment of page charges. This article must therefore be hereby marked "advertisement" in accordance with 18 USC section 1734 solely to indicate this fact. 
A

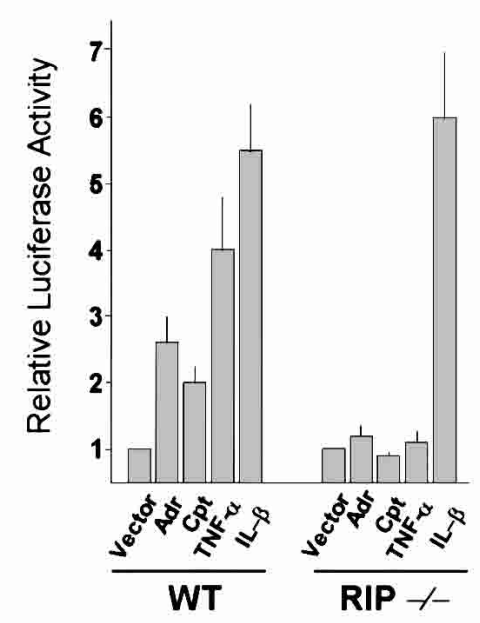

B
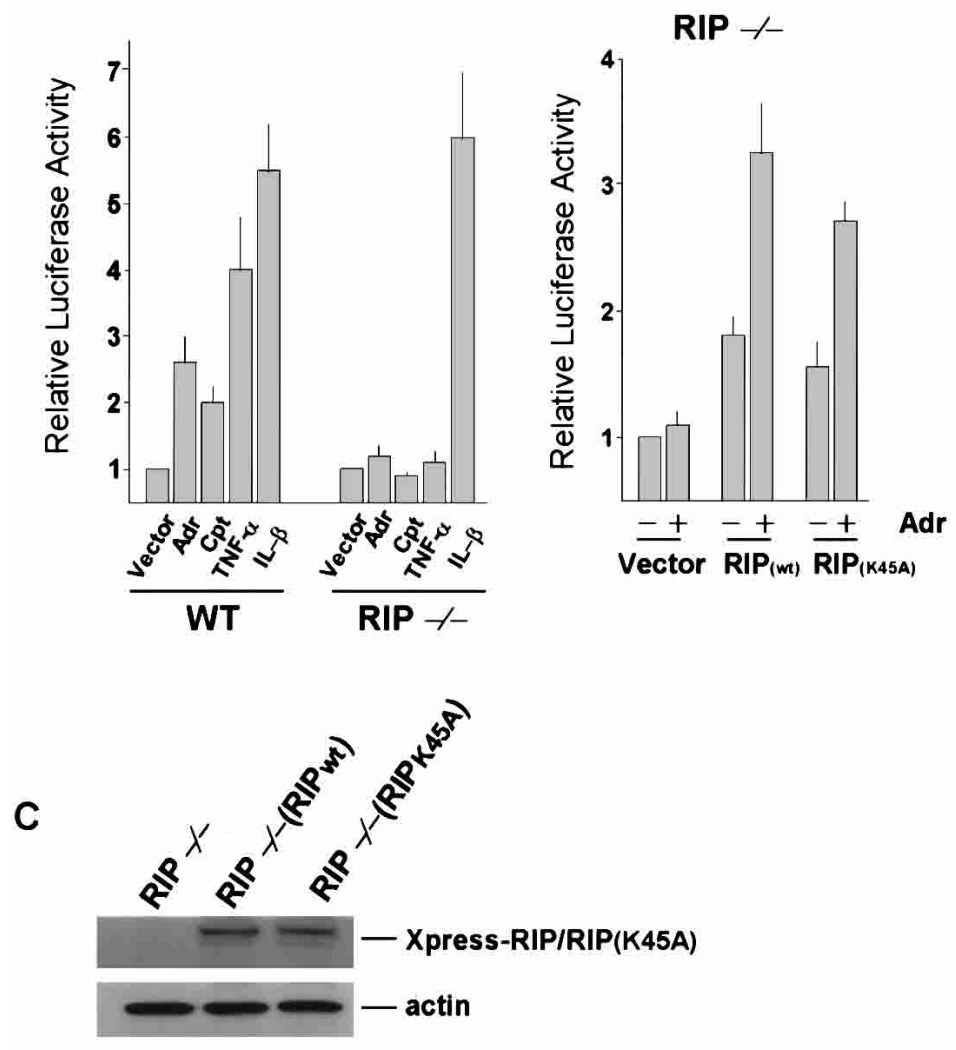

D
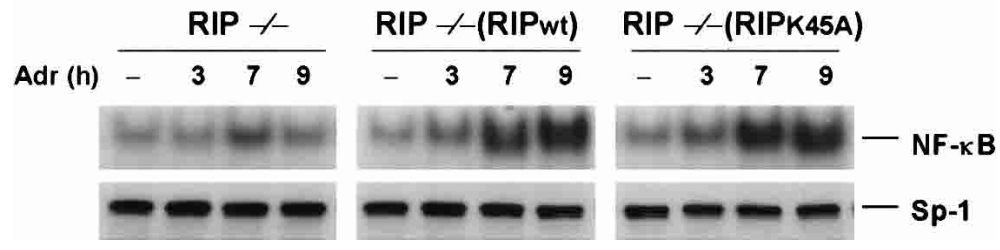

Figure 7. The kinase activity of RIP is not required for Adr-induced NF- $\kappa$ B activation. (A) Mouse wildtype cells and RIP-/- cells were transiently transfected with p2xNF-кB-Luc and pRSV- $\beta$-gal. pCMVcrmA was also included in the transfection to protect the cells from apoptosis induced by overexpression of RIP. After $24 \mathrm{~h}$ of transfection, cells were treated with Adr $(10 \mu \mathrm{g} / \mathrm{mL})$, Cpt $(100 \mu \mathrm{M})$, TNF- $\alpha$ (30 ng/mL) or IL-1 $\beta(4 \mathrm{ng} / \mathrm{mL})$ for $12 \mathrm{~h}$. The luciferase activity of each sample was normalized according to $\beta$-galactosidase activity. The data represent results from five independent experiments. $(B)$ Mouse RIP-/- cells were transiently transfected with expression vectors of the different RIP constructs (wild-type RIP or kinase-inactive RIP: RIPK45A) along with p2xNF-кB-Luc and pRSV- $\beta$ gal. After $24 \mathrm{~h}$ of transfection, cells were treated for $12 \mathrm{~h}$ with $10 \mu \mathrm{g} / \mathrm{mL}$ of Adr. Cells were then collected for measuring luciferase activity as described in $A .(C)$ The protein expression of Xpress-tagged RIP and RIP(K45A) in reconstituted stable cell lines, RIP-/-/RIP and RIP-/-/RIP(K45A). The same amount of cell extract from each cell line was applied to SDS-PAGE for Western blotting with antiXpress and anti- $\beta$-actin antibodies. $(D)$ Adr-induced NF-кB-binding activity does not require the kinase activity of RIP. RIP-/-, RIP-/-/RIP, and RIP-/-/ $\mathrm{RIP}(\mathrm{K} 45 \mathrm{~A})$ cells were incubated with $\mathrm{Adr}(10 \mu \mathrm{g} / \mathrm{mL})$ for various times as indicated. NF- $\mathrm{KB}$ activity was measured by EMSA as described in Figure 2.

\section{References}

Baeuerle, P.A. and Baltimore D. 1996. NF-к B: Ten years after. Cell 87: 13-20.

Bender, K., Gottlicher, M., Whiteside, S., Rahmsdorf, H.J., and Herrlich, P. 1998. Sequential DNA damage-independent and -dependent activation of NF-кB by UV. EMBO J. 17: 51705181.

Boland, M.P. 2001. DNA damage signalling and NF-кB: Implications for survival and death in mammalian cells. Biochem. Soc. Trans. 29: 674-678.

Bottero, V., Busuttil, V., Loubat, A., Magne, N., Fischel, J.L., Milano, G., and Peyron, J.F. 2001. Activation of nuclear factor $\kappa \mathrm{B}$ through the IKK complex by the topoisomerase poisons SN38 and doxorubicin: A brake to apoptosis in HeLa human carcinoma cells. Cancer Res. 61: 7785-7791.

Brown, K., Gerstberger, S., Carlson, L., Franzoso, G., and Siebenlist, U. 1995. Control of I $\kappa$ B- $\alpha$ proteolysis by site-specific, signal-induced phosphorylation. Science 267: 1485-1488.

Canman, C.E. and Kastan MB. 1996. Signal transduction. Three paths to stress relief. Nature 384: 213-214.
Chen, G. and Goeddel, D.V. 2002. TNF-R1 signaling: A beautiful pathway. Science 296: 1634-1635.

Devary, Y., Rosette, C., DiDonato, J.A., and Karin, M. 1993. NF- $\kappa$ B activation by ultraviolet light not dependent on a nuclear signal. Science 261: 1442-1445.

Devin, A., Cook, A., Lin, Y., Rodriguez, Y., Kelliher, M., and Liu, Zg. 2000. The distinct roles of TRAF2 and RIP in IKK activation by TNF-R1: TRAF2 recruits IKK to TNF-R1 while RIP mediates IKK activation. Immunity 12: 419-429.

Devin, A., Lin, Y., Yamaoka, S., Li, Z., Karin, M., and Liu, Zg. 2001. The $\alpha$ and $\beta$ subunits of ІкB kinase (IKK) mediate TRAF2-dependent IKK recruitment to tumor necrosis factor (TNF) receptor 1 in response to TNF. Mol. Cell. Biol. 21: 3986-3994.

Hallahan, D.E., Mauceri, H.J., Seung, L.P., Dunphy, E.J., Wayne, J.D., Hanna, N.N., Toledano, A., Hellman, S., Kufe, D.W., and Weichselbaum, R.R. 1995. Spatial and temporal control of gene therapy using ionizing radiation. Nat. Med. 1: 786791.

Hsu, H., Huang, J., Shu, H.B., Baichwal, V., and Goeddel, D.V. 1996. TNF-dependent recruitment of the protein kinase RIP 
Hur et al.

to the TNF receptor-1 signaling complex. Immunity 4: 387396.

Huang, T.T., Wuerzberger-Davis, S.M., Seufzer, B.J., Shumway, S.D., Kurama, T., Boothman, D.A., and Miyamoto, S. 2000. NF- $\mathrm{B}$ activation by camptothecin. A linkage between nuclear DNA damage and cytoplasmic signaling events. $J$. Biol. Chem. 275: 9501-9509.

Karin, M. and Ben-Neriah, Y. 2000. Phosphorylation meets ubiquitination: The control of NF-кB activity. Annu. Rev. Immunol. 18: 621-663.

Kelliher, M.A., Grimm, S., Ishida, Y., Kuo, F., Stanger, B.Z., and Leder, P. 1998. The death domain kinase RIP mediates the TNF-induced NF-кB signal. Immunity 8: 297-303.

Ko, L.J. and Prives, C. 1996. p53: Puzzle and paradigm. Genes \& Dev. 10: 1054-1072.

Kulms, D., Poppelmann, B., and Schwarz T. 2000. Ultraviolet radiation-induced interleukin 6 release in HeLa cells is mediated via membrane events in a DNA damage-independent way. J. Biol. Chem. 275: 15060-15066.

Laurent, G. and Jaffrezou, J.P. 2001. Signaling pathways activated by daunorubicin. Blood 98: 913-924.

Li, N. and Karin, M. 1998. Ionizing radiation and short wavelength UV activate NF-кB through two distinct mechanisms. Proc. Natl. Acad. Sci. 95: 13012-13017.

Li, N., Banin, S., Ouyang, H., Li, G.C., Courtois, G., Shiloh, Y., Karin, M., and Rotman, G. 2001. ATM is required for IкB kinase (IKK) activation in response to DNA double strand breaks. J. Biol. Chem. 276: 8898-8903.

Li, Q., Estepa, G., Memet, S., Israel, A., and Verma, I.M. 2000. Complete lack of NF-кB activity in IKK1 and IKK2 doubledeficient mice: Additional defect in neurulation. Genes \& Dev. 14: 1729-1733.

Liu, Z.G., Baskaran, R., Lea-Chou, E.T., Wood, L.D., Chen, Y., Karin, M., and Wang, J.Y. 1996a. Three distinct signalling responses by murine fibroblasts to genotoxic stress. Nature 384: 273-276.

Liu, Z.G., Hsu, H., Goeddel, D.V., and Karin, M. 1996b. Dissection of TNF receptor 1 effector functions: JNK activation is not linked to apoptosis while NF-кB activation prevents cell death. Cell 87: 565-576.

Shu, H.B., Takeuchi, M., and Goeddel, D.V. 1996. The tumor necrosis factor receptor 2 signal transducers TRAF2 and cIAP1 are components of the tumor necrosis factor receptor 1 signaling complex. Proc. Natl. Acad. Sci. 93: 13973-13978.

Siebenlist, U., Franzoso, G., and Brown, K. 1994. Structure, regulation and function of NF-к B. Annu. Rev. Cell. Biol. 10: 405-455.

Silverman, N. and Maniatis, T. 2001. NF-кB signaling pathways in mammalian and insect innate immunity. Genes \& Dev. 15: 2321-2342.

Singh, S.P. and Lavin, M.F. 1990. DNA-binding protein activated by $\gamma$ radiation in human cells. Mol. Cell. Biol. 10: 5279-5285.

Stanger, B.Z, Leder, P., Lee, T.H., Kim, E., and Seed, B. 1995. RIP: A novel protein containing a death domain that interacts with Fas/APO-1 (CD95) in yeast and causes cell death. Cell 81: 513-523.

Ting, A.T., Pimentel-Muinos, F.X., and Seed, B. 1996. RIP mediates tumor necrosis factor receptor 1 activation of NF- $\mathrm{BB}$ but not Fas/APO-1-initiated apoptosis. EMBO J. 15: 61896196.

Verma, I.M., Stevenson, J.K., Schwarz, E.M., Van Antwerp, D., and Miyamoto, S. 1995. Rel/NF-к B/I к B family: Intimate tales of association and dissociation. Genes \& Dev. 9: 27232735.

Zhang, S.Q., Kovalenko, A., Cantarella, G., and Wallach, D.
2000. Recruitment of the IKK signalosome to the p55 TNF receptor: RIP and A20 bind to NEMO (IKKgamma) upon receptor stimulation. Immunity 12: 301-311. 


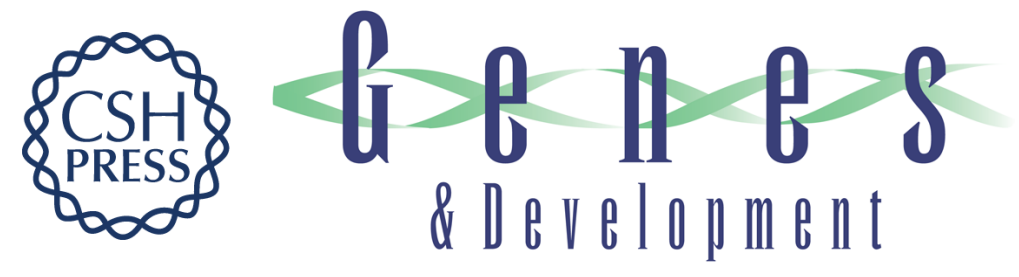

\section{The death domain kinase RIP has an essential role in DNA damage-induced NF- $\kappa$ B activation}

Gang Min Hur, Joseph Lewis, Qingfeng Yang, et al.

Genes Dev. 2003, 17:

Access the most recent version at doi:10.1101/gad.1062403

References This article cites 31 articles, 17 of which can be accessed free at: http://genesdev.cshlp.org/content/17/7/873.full.html\#ref-list-1

License

Email Alerting

Receive free email alerts when new articles cite this article - sign up in the box at the top Service right corner of the article or click here.

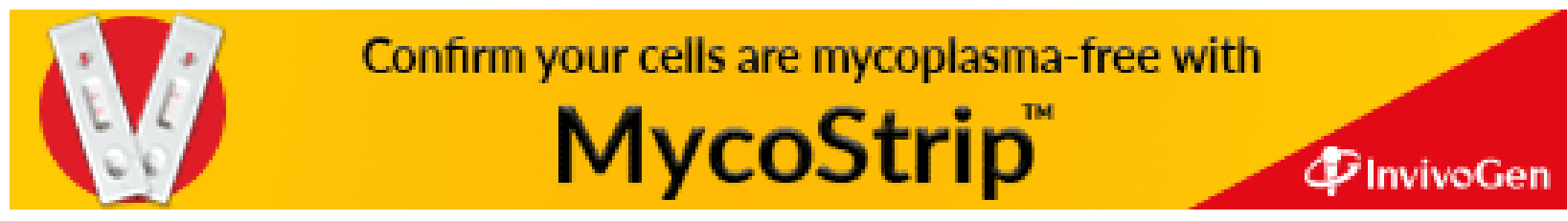

